\title{
VIDEOS AND VIOLENCE ON THE PERIPHERY: \\ RAMBO AND WAR IN THE FORESTS OF THE SIERRA LEONE-LIBERIA BORDER
}

\section{Paul Richards}

\section{INTRODUCTION}

Looking at possible research sites in eastern Sierra Leone in 1978 , I one day came across a striking cartoon executed in charcoal on the wooden window shutter of a mud-built house in an isolated village close to the Liberian border. It pictured a helicopter observing two village women pounding rice in a mortar. Seemingly the message was not only that 'modern' and 'traditional' are contemporaneous, but also that representatives of these two worlds are now engaged in mutual observation. The watchers within the helicopter are themselves observed; the village artist draws (and draws conclusions about) what has been seen.

The cartoon was prophetic. Over-run by guerrillas of the Revolutionary United Front (RUF) in April 1991, the Sierra Leone-Liberia border zone now finds itself under regular scrutiny from the air by warplanes of the West African Intervention Force.

This article outlines some ways in which the exposure of youth in the region to international electronic media has affected the course of this rebellion, spawned by the civil war in Liberia.

\section{DIAMONDS AND YOUTH ON THE SIERRA LEONE-LIBERIA BORDER}

Diamonds are the major mineral resource of the Sierra Leone-Liberia border region. Large-scale multi-nationaldiamond mining in Sierra Leoneceased some years ago, because of the difficulty in preventing freelance diggers creaming off the best stones; illicit mining is easily done by excavating swamps and stream beds during the dry season and sieving the gravel before the rainy season flood overtakes the makeshift workings. In the mid 1980s the government of Sierra Leone opened the concession areas fully to small-scale operators.

Sponsors of small-scale diamond mining operations (typically Lebanese, Guinean and Sierra Leonean traders, and government functionaries) hold a government licence to mine, and work concessions leased from local land owners. Licensed operators tend to operate on more accessible and betterserviced sites, at times using pumping and dredging gear. But there is a significant minority of unlicensed operators, frequently working remote government land, e.g. forest reserves along the Liberian border.

Miles away from roads and official scrutiny these squatters use only the simplest equipment - sometimes nothing more than a bucket, spade and sieve. The loyalty of diggers on the border to either the Sierra Leone or Liberian state has been dubious for many years; politically foot-loose, they were a prime target for recruitment by the RUF during the 1991 invasion of the border zone (Richards 1993).

Quite commonly the financial backer and licenceholder of a typical Sierra Leonean small-scale diamond mining operation will be permanently resident in town (having a business to run, or official duties to discharge). The mining operation is left largely to the initiative of a site foreman and crew of young labourers. This is typical on remote workings where conditions are at their most arduous, and regular supervisionby a sponsor impracticable. Four Limba miners, encountered miles off the beaten track in the heart of the Gola North forest reserve in November 1989, heading for Pandebu, a diamond village on the border, had been sponsored by a doctor in a government hospital in NW Sierra Leone. His chances of making a site visit - one day by road and a day's trek across the forest - were zero.

In most cases the sponsor supplies diggers with rice, tools, and often a shot-gun and cartridges to hunt for the pot. The digging crew generally split a two-fifths share of the local price for each season's haul of diamonds.

Much of the profit in diamonds is made in exporting them to Europe and the Middle East. Members of digging crews are sometimes tempted to abscond with large diamonds. This is not as easy an option as it might appear. Diggers lack 
the contacts, documentation and knowledge to sell directly on the international market. Collusionamong crew members is threatened by whistle-blowers, always well-paid by sponsors for information. The police also find themselves promptly rewarded for their vigorous pursuit of diamond cases. Not a few sponsors are well-armed and prepared to take the law into their own hands. Finally, and perhaps most crucially, an absconding digger will find it hard to sell a stone without provenance at anything approaching its true value. The main dealers have good local intelligence networks, and offer only minimal prices for suspect stones. Many diggers concede that it is hardly worth risking a long-term stable relationship with a sponsor for such dubious returns. They prefer to try and save enough from regular work to acquire a licence of their own.

Meanwhile, any ready cash is used to ease the hardship and tedium of life in the bush. The leisuretime activities of diggers are fairly basic. The occasional visit to town to stock up on supplies may offer the chance to see the latest films in cinemas and video parlours. Not a few young miners have partcompleted secondary (in some cases university) education, and thirst for knowledge of contemporary political events. During the Gulf War a Lebanese diamond dealer in Bo did good business re-broadcasting each morning in his cinema $\mathrm{CNN}$ footage of the Gulf War, taped from a domestic satellite TV installation during the night. In the bush, crews relax with music, radio, drink, gambling and recreational drugs (mainly cannabis, but 'crack' cocaine is increasingly available). At weekends and holidays itinerant video shows touted around the camps and villages of the mining areas are a greatly welcome diversion.

\section{RAMBO AND REALITY}

'Abdul' and 'Yusuf' are now in their mid-thirties. They were early drop-outs from Koranicschool; their father, a Mandingo merchant from Guinea, forbade other forms of educa tion on religious grounds. When teenagers, they ran away to the diamond-mining areas, where they picked up work as labourers on unlicensed diggings. Unmarried, and still dreaming of making their fortunes in diamonds, Abdul and Yusuf today scrape a living touring the remote mining localities of the border zone, showing films on a borrowed video machine powered by a portable generator. The video player and generator belong to a friendly sponsor in Bo.
A token payment (perhaps some free tickets) to the village chief and elders secures the use of the opensided village court house - the bari. Abdul borrows benches from the school. Yusuf is busy stringing up old sheets and rush mats to block the sight lines of by-standers without tickets. As darkness falls Abdul sells tickets, while Yusuf tinkers with the generator. Around eight the machine kicks into life, and the show begins. Perhaps 50 or 100 people (young men from the diamond workings, but also village people) have paid about $30-50$ pence each to see a Hong Kong Kung Fu epic, or Hollywood's latest attempt to live down the nightmare of the Vietnam war.

Abdul and Yusuf typically exploit a pitch for about a week, and then move on to the next largish village a few kilometres down the road. Some of their takings are needed to buy fuel for the generator and pay other local expenses and some is set aside to return to the owner of the set and films. The balance (perhaps a third) is profit, to be saved for the day when they will have enough to buy a licence and mine for diamonds on their own account.

Abdul and Yusuf are articulate about audience tastes. They know that 'action' films (essentially a genre comprising Kung Fu and American war movies, but including violent science fiction epics such as Terminator) have the greatest drawing potential among their best customers, the diamond crews. But Indian 'love' films also attract good audiences.

Indian films, Yusuf explains, are about social relationships; about how to build such relationships for a long-term future. Young women like them a lot for this reason, but women are in a minority in diamond camps. Women are prevented from visiting work sites for fear of spoiling the diggers' luck (heija).

Action films appeal because they are regarded as teaching the skills and attitudes needed to survive on your own in a hostile world (See Appendix). Rambo is especially admired. In Abdul's enthusiastic retelling of his hero's death-defying tricks it is not hard to detect echoes of Musa Wo, the trickster figure whose wilful schadenfreude is tolerated within the Mende moral universe as a harbinger of fruitful new social trends (Cosentino 1989).

Rambo films, Yusuf asserts, are a window on reality. 'We Africans' he says 'are slow to learn, but films help bring home quickly what the world is like, and the tricks you need to survive'. Rambo prepared him, 
he claims, to understand the first news of the RUF invasion of eastern Sierra Leone in April 1991. 'We were excited' he says 'that change was coming'; specifically that the rebels would sweep away the corruption and inertia of the two decades in which an APC regime had presided over a collapsing economy, and sharply diminished educational and employment prospects.

Abdul and Yusuf both had wondered briefly about joining the rebels. Possessing little property themselves they may not have been deterred by villagers' reports of extensive looting by the RUF. They were alarmed, however, by the evidence of widespread wanton and terroristic violence against civilians. Quickly sensing that behind the RUF was a group of business speculators not significantly different from the class of sponsors currently in the driving seat of the diamond economy, Abdul and Yusuf's moment of infatuation with the idea of rebellion soon passed. Both had become enthusiastic supporters of a youthoriented NPRC military regime. They now anxiously wait for the moment the rebellion will be finally quashed so that they can head east and resume life on the road with their small dream machine.

Yusuf thought the diamonds would always be there - new ones work their way upwards from deep in the ground all the time. They carry within them their finder's names, if only the finder has the courage to keep on looking. If the mining economy ever collapsed, he would go back to farming - cassava, probably. Abdul mocks him for his lack of foresight; 'how will he ever make a farm "with a slack body" ', the brother cruelly observes.

The news is that Tongo Field is reckoned secure from further rebel advance. Later in the day Abdul and Yusuf are seen heading for the Kenema motor park, their total possessions squeezed into a small box hardly larger than a woman's handbag. They are planning to wash gravel until the dry season arrives. They will then return to Bo for their equipment and the new season's crop of videos.

\section{VIDEO VIOLENCE AND YOUTH REBELLION}

\subsection{The RUF Rebellion}

The roots of the RUF seemingly lie in a period of intense student opposition to Siaka Stevens in the 1970s. Libya provided refuge for a number of student activists exiled by Stevens. More recently some RUF activists (the movement claims to have been formed in 1982) undertook guerrilla training in Benghazi preparatory to launching an invasion of eastern and southern Sierra Leone from territory controlled by Charles Taylor's National Patriotic Front of Liberia (NPFL) faction in Liberia. Foday Sankoh, leader of the RUF, and other members of the movement, fought alongside the NPFL when it entered Nimba County (Liberia) from Cote d'Ivoire in December 1989. Taylor promised support for the Sierra Leone rebellion in return. During the early stages of the RUF incursion into Sierra Leone, April-July 1991, much of the fighting was in the hands of NPFL fighters and Burkinabe mercenaries, while large numbers of Sierra Leonean youths - including many diamond diggers from remote workings along the border - were recruited for military training. In some cases adhesion may have been voluntary. But in other cases recruitment was by force; backsliders appear to have been compelled to take part in atrocities against local civilians, to break decisively their ties with the local community. Loyalty to the RUFwas further guaranteed by tatooing the young recruits, thus readily identifying deserters and threatening reprisals from government forces.

The origins of the RUF are opaque, as are its political aims. It was unknown within Sierra Leone until it launched its military campaign in March 1991. With only slender resources, its field plan seems to have been to try and provoke the collapse of the government of President Momoh as much through the ingenious application of terror tactics as through limited military engagement along the border. The locally recruited 'youth army' was at first more a means of demonstrating local political support than a fighting force.

Plans appear to have been blown off course by greater than anticipated military opposition. Much of this came from Liberian irregulars hastily recruited from among the many refugees in Sierra Leone opposed to the NPFL. RUF progress through the diamond districts of eastern Sierra Leone was also restricted by Guinean troops fighting under the terms of the Sierra Leone-Guinea defence pact, during which time the small and ill-equipped Sierra Leone army was able to improve its basic military competence.

The rebels were then pushed back towards the border in August-September 1991, but further progress by Sierra Leone forces was undermined by ineptitude and corruption within the government. This led to a protest by young officers from the war 
front over pay and equipment that escalated into a coup against President Momoh in April 1992. The new National Provisional Ruling Council (NPRC) military government, recognizing the extent to which the RUF rebellion was a campaign for the hearts and minds of disaffected youth within Sierra Leone, promptly organized a vigorous and effective youth secretariat NASMOS to carry out a number of urban renewal campaigns. Regular street cleaning and wall painting (some apparently spontaneous manifestations of popular support for the NPRC regime) have served since to symbolize the repair of many years of corruption and neglect under the APC (Opala 1993).

Having been out-gunned by the NPRC for the loyalty of Sierra Leonean youth the RUF seemingly re-focused its war aims on more strictly material targets. The October-December 1992 campaign to captureand control diamond-rich Kono Districtmade overt the concern of the RUF's alleged French and Ivoirian-based business backers to divert the flow of Sierra Leone's diamonds from established Guinean and Senegambian networks towards Abidjan, via Taylor's 'Greater Liberia'.

Suspension of its political programme in favour of diamond mining ended any RUF claims to the moral high ground in Sierra Leonean politics (claims earlier tarnished by the brutality of the Liberian and Burkinabe mercenaries fighting on its behalf). Ordinary Sierra Leoneans found there was little to choose between RUF war-lords and the political lackeys of the rich diamond mining 'barons' they sought to replace (not to mention those government troops allegedly too busy digging diamonds to secure the state's defences). Military reverses in late 1993 may have spelt the end of the RUF as a force for youth rebellion in Sierra Leone.

\subsection{The blighted dreams of youth}

The 10-18age cohort in Sierra Leone has risen from 15 to 20 per cent of the total population since the first census in 1963. In some ways it this group that has borne the brunt of recent economic decline. The school system is collapsing and job prospects are minimal, external aid is tied to structural adjustment and progress towards democratization. IMF-led fiscal prudence threatens to constrain educational opportunities still further. But not even the most doctrinaire supporters of Western systems of representative democracy seriously propose reducing the voting age to incorporate ten-year old children on the street. 'Democratization' offers little or no immediate appeal to this youth cohort. Instead, young people turn to the products of the international media industry for political solace. Cheap or free, and readily accessible, global media products are one of the few changes for the better in the lives of these young people in recent years. Where once educational advancement beckoned, the bright light of hope on the political horizon is now provided by reenacting the exploits of Rambo and Ninja Turtles.

Aneye-witness in NPFL head-quarters town Gbarnga in 1990 described five generator-driven video parlours running 24 hours a day to supply young rebel fighters with a diet of Rambo and Terminator-style films (Richards 1993). This raises the question whether rebel strategists were simply building upon established patterns of entertainment, or had it in mind from the outset quite consciously to manipulate to their own ends the mythic revolutionary charters already part-elaborated from international media materials by the mobile, media-conscious youth of these remote rural regions in interior Liberia and Sierra Leone.

A number of press reports have commented on the Rambo or Kung-Fu dress styles affected by young NPFL and RUF fighters in the field. Some rebels have been filmed or photographed kitted out in battle dresses comprising horror-comic masks, wigs and women's dresses. Attracted to the bizarre like wasps to jam, the Western Press implicitly contrast this 'inexplicable' behaviour with the 'clean','rational' warfare of Western armies in the Gulf (Moran 1994). But far from being inexplicable, the costumed fighter (Mary Moran argues) is a reversion to the idiom of pre-colonial African warrior, in which individuality of costume was expressive of a mastery of all kinds of trickery and deep inner resourcefulness.

The image of the uniformed, dragooned, government foot soldier sums up for the rebel (Moran suggests) some of the key contradictions of African (post-colonial) modernity. The Liberian dictator Doe, focus of NPFL hatred, was the very embodiment of the unreflective, ill-trained and brutal soldiery upon which West African states, imploding with corruption and the strains of structural adjustment, depend for their political 'stability'. Hope for these young revolutionaries, therefore, resides in rejecting conventional military uniform and reviving the brilliant unconventionality of the pre-colonial warrior tradition. 
Invoking the warrior's spirit some NPFL and RUF rebels relate their costumes to the established masquerades of the region (hunter's dances for example, in which the new and old are brought together in jarring juxtaposition). Others opt for the brilliant modernist inventions of Bruce Lee, Rambo or a pack of Ninja Turtles. Either way, the message seems to be that failed structures can be swept aside, and new political beginnings launched, only through the cleansing actions of the warrior, attired beyond the bounds of convention, in garb that speaks of inner resource and supreme cunning.

\subsection{Child soldiers}

Seemingly, the NPFL was the first armed faction in the region to recruit, train and field under-age fighters (some ten-years old or less). Under-age fighters are said to be particularly effective in battle because they are unrestrained by fear or convention. They make up in warrior-like resourcefulness what they lack in strength or experience. The RUF copied the NPFL, and battle-front commanders of the Sierra Leone government forces, seeking to fight fire with fire, followed suit. Under-age troops on the government side have now been stood down and are undergoing rehabilitation. Evidence of deployment of child soldiers in the conflicts in Liberia and Sierra Leone is consistent with my argument that these rebellions reflect a concern for political empowerment on the part of an age group normally considered too young to participate in representative democracy. Supporters of democracy within Africa may have to debate at what age citizens begin to vote in a region where, typically, half the population or more is under 18 years old.

\section{CONCLUSION}

First let me be clear about what I not arguing - I am not suggesting that violence-as-entertainment is a cause of war in the Sierra Leone-Liberia border zone.

\section{APPENDIX}

\section{A note on youth exposure to video in Sierra Leone}

About 200 young Sierra Leoneans have been interviewed concerning their leisure pursuits and exposure to electronic media, as part of a study of their awareness of conservation issues in West Africa (an ESRC-funded study jointly directed by Philip Burnham, Michael Rowlands and myself). The following results derive from a sub-sample of 65 inter-
What I am suggesting is that the ready availability and recent spread of violence-as-entertainment meets a widespread political need among youth in the region - the need to celebrate the unconventional inventiveness of those (primarily the young) who are as yet outsiders to the political process. I have no military knowledge, but somehow I doubt Rambo and Kung Fu films convey any useful practical information about combat. The interpretations young Sierra Leoneans read into this material concern the neglected potential value to society of the quickwitted inventiveness of the young (see Appendix), rather than the practical utility of violence. I do think, however, it likely that the organizers of the NPFL and RUF rebellions seized upon this youthful enthusiasm for violence-as-entertainment as a recruiting ploy, and later were happy to tap its military and terroristic potential. There is evidence to suggest that, having hooked their followers, RUF and NPFL commanders set about converting violence-as-play to violence-for-real by embroiling young enthusiasts in terroristic atrocities from which there was no hope of return. We should hesitate to blame Rambo for cynical exploitation of youthful enthusiasm by opportunist elders as old as history itself.

Although there has been insufficient space in this short article to deal with gender dimensions of the RUF rebellion, it should be noted that 'action' films appeal to young women also (see Appendix), and young women joined the RUF as battle-field combatants. Since the young women I have interviewed tend to be more shrewd than young men in their assessment of the propensity for real violence to spread with unmanageable consequences, this enthusiasm for 'action' films may add strength to the conclusion that, in the absence of any experience of the violent realities of war, the basis of the RUF's appeal was the scope the movement appeared to offer to those concerned to celebrate the cleverness of unenfranchized youth. views from young people living in Bo, Freetown and Kambia District. Fifty three (86 per cent) had some exposure to films on video. Of these, 19 (36 per cent) claimed a preference for films they categorized as 'war', 'action' or 'Rambo'; 9 were females, 14 Muslims and 15 had secondary or post-secondary education. Nearly all the sample thought they acquired valuable information or vicarious experience about life from watching such films. Females tended to 'read' such films as warnings about potential future dangers (including men!), and when to flee (the 
comment by the young women who felt a knowledge of Rambo films had given her the courage to flee through the bush to escape the rebel invasion of Kono is especially poignant); males tended to imagine that videos of violence added to their skill in fighting.

Male reasons for preferring violent videos:

- 'to learn about methods of self-defence'

- 'teaches you how to manoeuvre in times of trouble'

- 'shows how strength is displayed'

- 'it is pleasing'

- 'to gain some skills'

- 'teaches you how to be strong for the future'

\section{REFERENCES}

Cosentino, D., 1989, 'Midnight charters: Musa Wo and the Mende myths of chaos.' In W. Arens and I. Karp, (eds) The Creativity of Power. Washington: Smithsonian Institution Press

Moran, Mary, 1994, 'Warriors or soldiers: masculinity and ritual transvestism in the Liberian civil war', in C.R. Sutton (ed) Feminism, Nationalism and Militarism,
- 'to know about fighting'

- 'to gain ideas about wars and know skills for fighting'

- 'because of the action, and because it is educative'

Female reasons for preferring violent videos:

- 'it solved my problem, it helped me run away from (the rebels) in Kono'

- 'how to use techniques to defend oneself'

- 'to learn the dangers of war'

- 'to tell us to be aware and ready at any time'

- 'to get awareness of what is ahead, to learn more about men, and the whole of the world'

- 'for self-defence'

- '(enjoyed) the actor displaying might in the bush'

Arlington VA: American Anthropological Association for Feminist Anthropology

Opala, J. A, 1993, 'Ecstatic renovation: street art celebrating Sierra Leone's 1992 revolution.' mimeo, April 1

Richards, P., 1993, 'Rebellion in Liberia and Sierra Leone: a crisis of youth?' in O.W. Furley (ed) Conflict in Africa, forthcoming: Ch. 5 